\title{
Science and Technology for Raising Income: The Choice of Activities, the State and the Private Sector
}

\section{Sikander Rahim*}

\begin{abstract}
Pakistan's lack of industrial progress over decades should be cause for concern about the future. The goods the economy produces competitively are the typical goods that yield so little income that they are only exported by economies that have low wage labour. They are much the same manufactures now as during the 1960s and have been kept competitive by keeping wages down through repeated devaluation. Income per head will rise slowly, at best, if the economy does not learn how to produce goods that yield more income, and that means acquiring the up to date technical knowledge needed to be competitive from the foreign producers who produce such goods. But that is knowledge obtained through $R \& D$ and is not provided freely, least of all to would-be competitors. Pakistani firms can try to do their own R\&D, but, even with public sector collaboration, they cannot catch up with the established foreign firms, which continue to do their $R \& D$ and have more money, experienced staff and facilities. The two possibilities are to attract foreign direct investment and for Pakistani firms to insert themselves into the production processes of foreign firms. Experience shows that the first, though it has worked well in several countries, can be ruled out for the present; there has been no FDI in Pakistan for making exportable manufactures. But economies like South Korea and China acquired the technical knowledge they needed through subcontracting and joint ventures with American, European and Japanese firms and moved on from there. There is no realistic alternative and task ahead is to determine what has to be done to realize it.
\end{abstract}

Keywords: Science and technology, R \& D, productivity, innovation, Pakistan.

JEL classification: $\mathrm{O} 14$.

\section{Introduction}

Awareness of the need to improve Pakistan's capabilities in the natural sciences and technology is now practically universal. This was not always so. On the contrary, there is an embarrassing history of how education and science were ignored, even looked down on, during the first

\footnotetext{
${ }^{*}$ Former World Bank, Washington D.C.
} 
decades after Partition and the result has been the present deficiencies in these capabilities.

This new awareness is partly the result of efforts by some economists to draw attention to the importance of science and technology (S\&T), an early example being the workshop organized by the Lahore School of Economics and Dr Irfan ul Haque in 1997. Since then, there have been some extensive reports on the subject, notably that of the collaboration between the Pakistan Institute of Development Economics and the Higher Education Commission of 2003 and that of the Ministry of Science and Technology of 2013. Part of the reason for this awareness has been concern about military and security matters - this has resulted in achievements that go far beyond what has been achieved in mundane economics, but yielded little direct economic benefit.

Since S\&T have been generally neglected, the two reports just mentioned are intended to be comprehensive. They try to assess the needs and possibilities of the whole country, covering a wide range of topics, including electronics, microbiology, new weaving techniques and the Large Hadron Collider. This conference's agenda is more specific: it is concerned with the S\&T needed for economic progress, especially productivity. The purpose of this paper is to discuss one question: what S\&T do we need to raise incomes in Pakistan? This leads to other questions: how do we get the S\&T needed and what can and should the public sector do?

\section{Diversifying Out of Low-Wage Goods: Why and How}

First, the question of raising income. In the long run - and even in the short run - the sustained growth of income must come from manufacturing and, when possible, from technical services. However, the kind of manufacturing done here will not raise incomes. To take textiles and garments as an example, the types that are produced in Pakistan are produced here because wages are low in foreign exchange terms. High-wage countries no longer produce them and Pakistan would not produce them either if wages here were to rise. In addition, the main markets for Pakistan's textiles levy import duties on them, which lowers the prices and income received from this kind of manufacturing even more.

A good rule for manufactures is that those that are simple to make are already being made by many firms in many countries with low-wage labor and competition keeps their prices from rising. Improving productivity is of little use here. If Pakistani textiles producers are simply 
inefficient in the sense that they could produce more with the same labor, equipment and raw materials, there may be some gain in income from reducing that inefficiency, but this is clearly not the road to riches.

Alternatively, productivity may be improved by using more advanced production techniques, but the same can be expected of competitors in other low-wage countries. There may be a transitory gain of income, but after that the high-wage countries benefit from lower prices. Textiles, other than some special fabrics, will not become high-wage goods and the cost of capital equipment needed for the new techniques should be counted against any gain of income.

If wages and, therefore, income per head are to rise, the country must move to making other types of goods - ones that are less simple to make. This raises the question, what has prevented Pakistani firms from making these goods already? As the theme of this conference indicates, one answer is Pakistan's low level of S\&T, both in the education system and in the workforce.

To formulate this more precisely, most manufactures - leaving aside the ones that are simple to make - are constantly evolving as the firms that produce them spend on research and development (R\&D) to improve their designs. This can be illustrated by the example of the motor car. A few big firms spend large amounts of money to improve the many different components of their brands of cars; the result is that cars improve a little each year. The cumulative effect over time is that a car made 10 or 15 years ago is technically far behind a new car. If a car were made now using the technology of 10 or 15 years ago, consumers would not buy it unless the price was sufficiently low, in which case the price would probably be too low to cover the production costs even in a low-wage country such as Pakistan, however efficient the production. The same reasoning applies to manufactures as various as entertainment equipment, household appliances and industrial machinery. Those manufactures to which it does not apply are the simple goods, especially those bought by the poor and already being produced in low-wage countries.

The technical knowledge generated by $R \& D$ is the intellectual property or proprietary knowledge of the firms that carry out the R\&D or pay for it and is protected by patents and secrecy. Since a large part of competitiveness consists of having up-to-date designs or versions of goods, the firms producing those goods do not impart their up-to-date knowledge to potential competitors. Were a Pakistani firm to start manufacturing a 
good in competition with established producers, the technical knowledge it would have available immediately would be out of date. It could invest in R\&D, but it would not catch up with the established producers, who would continue with their R\&D and maintain their lead, apart from being able to spend more.

Hence the dilemma of low-wage countries: they can invest in trying to compete with established producers of goods that evolve with R\&D or they can invest in the production of low-wage goods for which R\&D is unimportant. To do the former, they must have protected domestic markets since they cannot rely on exports in competition with established producers producing more advanced versions of the same good. However, countries like Pakistan that depend on foreign aid to avoid balance-of-payments crises have had to enter into agreements to reduce their trade barriers irreversibly. They do not have the option of protecting their uncompetitive industries.

The alternative that holds out the best prospects for Pakistan and which many firms in low-wage countries have discovered is to enter into the production of more complex goods - what is sometimes called entering the value chain. This is made possible by the way high-wage country firms have divided their production processes so as to assign the production of specific components of a good or stages in its manufacture to low-wage country firms, thus lowering their costs. A low-wage country firm can contract with a high-wage country firm to produce specific components or carry out processes that do not require special skills or proprietary knowledge.

This activity, which is referred to here as subcontracting, is necessarily a low-wage activity at first, but has three benefits. One is that it diversifies and increases the country's exports. A second is that it can increase the employment of more highly trained workers and engineers, depending on the type of activity - this means more income because these people are more highly paid. The most important benefit is the third: it can lead to technically more advanced activities. The experience of South Korea and China has been that, when a local firm establishes a stable relation of this sort with a high-wage country firm, the latter often increases the range of activities it assigns to the former. This usually means producing components that do require some special skills for which the high-wage country firm can send its own technical staff to give the training needed to make that component according to its own design and specifications. Step by step, this leads to taking over more of the production process because the low-wage technically qualified staff allow the partner high-wage country firm to save labor costs. 
An indication of its success in other countries is that the trade caused by subcontracting has been reduced. The reason is that firms that began by doing little pieces have grown able to do more and more, which has allowed the firms for which they were subcontracting to give them a greater share of the production. ${ }^{1}$

Another alternative is to attract foreign direct investment. No hope should be put in this. Pakistan's authorities have been doing what they can to provide all the conditions that are supposed to please foreign investors, but the results have been modest. Since conditions in the country are difficult, foreign investment is not easily attracted. Some (much of it, perhaps) Pakistani capital that had left the country is now coming back in the guise of being foreign, but none of this investment has been in new manufactures that could be exported or compete with imports. It has all been for captive markets such as electric power, phone services and fertilizers. For that to change, Pakistan has to have some success in diversifying its exports, especially in collaboration with foreign firms that would improve its standing as a place for investing in manufacturing.

\section{Education: The State and the Private Sector}

Put briefly, the argument here has two parts. The first is that Pakistan can only count on being able to raise its income from production by raising wages. This can only be done by entering into activities that are not lowwage activities - activities in which the country cannot compete unless it keeps its nominal wages down in terms of foreign currencies. The economic history of Europe and America shows that industrial and technical progress was stimulated by rising wages, which induced firms to find ways of increasing output per worker and to supply new and better goods for the demand from rising income. When production is confined to low-wage goods, nominal wages must be kept down for competitiveness, which is achieved by repeated devaluation. The data on wages are poor in Pakistan, ${ }^{2}$ but it seems that the nominal wage in constant dollar terms is lower now than it was in 1960.

The second is that activities that are not low-wage activities are necessarily ones that cannot be performed by unskilled workers alone. They require technical knowledge and it is in their nature that their specifications will change frequently. Obviously, such activities need technically trained staff who can assess their firms' abilities to undertake specific

\footnotetext{
${ }^{1}$ Financial Times, 3 March 2016, p. 3.

${ }^{2}$ They are surprisingly bad, especially in comparison with the data from the 1950s and 1960s.
} 
subcontracting, notably the detailed specifications, costs and timetables, and who would organize the work. These would normally be engineers and scientists with good university degrees and some experience. The work itself has to be carried out by workers able to acquire the appropriate skills as they change, to learn unfamiliar tasks and to read instruction manuals well enough to use them and to follow translated instructions. For this, workers must have the educational basis; they must have had the schooling to give them the necessary literacy and numeracy as well as enough background in science to adapt to changes as their tasks change. Workers with little or no education who learn their work by example or with brief instruction are rarely able to acquire the skills as quickly or to adapt as well as workers with the right kind of schooling.

Since these activities are being performed in competition with other countries, the education and technical training of the workers have to be suitably good. Firms that do not have the right workers can only succeed in low-wage activities. The education system must, therefore, provide the needed education to children of manual workers because clerical workers and professionals are less likely to send their children to be prepared to work on the shop-floor in factories. In addition, vocational training should not only complement basic schooling with as much training in the specific vocation the worker chooses, but should also guide the worker's choice in response to the needs expressed by firms. Ideally, vocational training would be accompanied by on-the-job training, especially through apprenticeship, though this has proved hard to institute in the few low-wage countries that have tried it.

The general need for more and better higher education in the sciences is well understood and need not be stressed here. Pakistan's capacity for providing such education is so limited, however, that the essentials have to be stated. The subjects that should be given priority are those most needed for the kind of subcontracting discussed in these remarks. At the same time, given the need for adaptability to changing foreign demands, education has to be a continuing process. There have to be institutions for updating and broadening the knowledge of the technical staff of firms at all levels.

Often, courses can be given by Pakistani specialists who have been working in firms that have given them the experience and expertise that do not come in classrooms. This is a common practice and does a little to reverse the brain drain. For example, in the 1950s about 80 percent of the South Koreans who went to the US to study sciences or engineering stayed there. 
This was an economic cost to South Korea, but some of it was recovered when the economy began to grow and to offer opportunities that attracted Koreans working abroad who could bring abilities they had acquired from their employment. Such an outcome may be a long way off for Pakistan, but attracting highly qualified people, especially retirees, for short courses is standard practice in many countries.

Pakistan has come to rely on the private sector for much of its education at all levels, mainly because the state has attached little importance to it. It may sound strange now, but in the 1950s and 1960s the government and planners, including Pakistan's foreign advisers, thought of education in Pakistan as perhaps socially desirable, but something that would have to be left to later, to a time when a 'breakthrough' in industry had occurred - rather like a dessert one got only after eating one's vegetables. Partly, it was a problem of social class: those who held power could arrange for their children to be educated in the existing schools in the country or be sent abroad, especially for higher education. The growth of private educational institutions shows how important virtually all families consider education to be and how much they sacrifice for their children to have it.

Governments show more awareness now of education's importance, but they have not yet tried to determine and state explicitly the kinds of education that are prerequisites for raising the country out of its continual poverty. The private sector cannot be expected to specify the kind of education needed for the future either, for it responds to expressed demand and not much of that demand has been directed towards S\&T. There are several reasons for this. One is that many scientific and technical subjects are costly to teach because they require properly equipped laboratories and workshops and consume chemicals and raw materials. Not many families can afford such education for their children. Computer classes and IT have the advantage of having some fixed equipment that can be used by successive classes and needs little space, and that makes them affordable and popular.

Another reason is that the primary and secondary schools in Pakistan only bring a few of their pupils to the level needed to study science or engineering at a good university in Europe, Japan or the US. For the present, the only way to increase the quantity and quality of primary and secondary education in preparation for studying S\&T at university level is for the state to provide the education free of charge in the public sector, with scholarships and other subsidies for pupils at private schools. 
The preparation of skilled workers, scientists and engineers needed to be competitive with foreign firms has to begin in primary school and continue through secondary school. The earlier the start, the better the final training or education. More public or private sector financing for wellequipped laboratories and workshops in secondary schools is greatly needed, though it would be unrealistic to expect much. Even vocational training is poorly supplied. Greater emphasis on mathematics goes some way to filling the gap. It provides a foundation that makes it easier to enter nearly all the sciences and branches of technology and requires no expensive equipment. It also develops numerical aptitudes and some of the process of scientific thinking, especially because it requires solving problems and is incompatible with rote learning. The extent to which mathematics is an indication of scientific ability is shown by the loud criticisms and complaints of industries and educationists in Europe and America over the degree to which the children in their schools perform less well in that subject than children in Chinese, Japanese and Korean schools.

To sum up, almost everyone in Pakistan regards education as essential for improving one's prospects, but the quantity and quality of education in technical subjects provided after secondary school are inadequate. There are two reasons for this. One is inadequate preparation: the level of scientific and mathematical teaching in primary and secondary schools makes it harder for pupils to enter S\&T at the level of a good foreign university. The second is a supply constraint: nontechnical subjects are easier to teach because they require little more than classrooms and teachers are easier to find. There have been remarkable successes, especially in matters of defense, and some scientific education is of high quality, but they are not designed to raise education standards in the natural sciences and related subjects in the way needed.

This is not to advocate an intellectual monoculture. On the contrary, if living standards can be raised for the mass of the population, cultural demands will increase and it is unlikely that the intellectual and artistic exuberance that has been manifest in recent times will fade because of better science teaching. The criterion for improving the teaching of technical subjects and the sciences is whether or not it allows Pakistan to diversify into collaborating with foreign firms so as to produce goods that will yield more income than do the low-wage goods produced here now. 


\section{A Final Comment}

Two conclusions can be left tactfully to the end. One is that increasing productivity does not help. Greater productivity with low-wage goods ends up lowering prices and is all to the benefit of the high-wage countries. This has been much discussed with agricultural products such as coffee and cocoa, of which the prices have been a diminishing part of the prices of the final goods made from them. There is no reason it should be different with textiles or garments. Second, innovation is neither possible nor necessary. It is unlikely that a firm or individual in Pakistan can invent some good or method that becomes exportable and has not been discovered by firms in high-wage countries, even if it cannot be logically excluded. So, Pakistan's firms are not going to spend much money on R\&D to innovate and the state's budget is too small for any serious effort outside defense.

At best, innovation would consist of adapting goods or production methods to Pakistani conditions. What matters at this stage is that firms be able to adapt to the innovations of producers of other countries and the changes these innovations require of the products that Pakistani firms make as subcontractors. At a later stage, when some firms have reached the point of supplying components for foreign firms on a large scale, it may be worthwhile for these firms to invest in R\&D in collaboration with their foreign partner firms. 